\title{
CONTEXTO E PROBLEMATIZAÇÃO DO FETICHISMO NA OBRA DE MARX. DOS GRUNDRISSE (1857-58) A O CAPITAL (1873)
}

\author{
CONTEXT AND PROBLEMATIZATION OF FETICHISMO IN THE WORK OF MARX. OF THE \\ GRUNDRISSE (1857-58) TO THE CAPITAL (1873)
}

Victor César Fernandes Rodrigues*

\section{RESUMO}

O presente artigo visa oferecer uma contribuição ao estudo do problema do fetichismo a partir da obra de Marx, indo dos Grundrisse de 1857-58 à segunda edição d'O capital de 1873. Pretende oferecer ao leitor uma contextualização acerca desse problema, tentando demonstrar que a formulação teórica do fetichismo da mercadoria exposta em $O$ capital é resultado de intensas análises anteriores de Marx. Com efeito, sua intenção é trazer a discussão para o fato de que é a temática da reificação exposta nos Grundrisse que engendra a formulação teórica do fetichismo em $O$ capital. Assim sendo, no marco dessa contextualização, faremos uma problematização sobre os possíveis avanços da referida temática para além do primeiro capítulo d'O capital, cuja análise versará em demonstrar que o fetichismo da mercadoria reúne em si um conjunto de questões candentes para Marx, as quais estão expostas em obras anteriores a 1873 - data em que Marx publica a segunda edição d' $O$ capital, que situa a problemática do fetichismo em um capítulo a parte, - e que demonstram pertencerem a um mesmo vínculo teórico relacionado ao problema da reificação e do fetichismo como categorias analíticas indissociáveis.

PALAVRAS CHAVE: Fetichismo. Reificação. Grundrisse. O capital.

\section{SUMMARY}

This article aims to offer a contribution to the study of the problem of fetishism from the work of Marx, going from the Grundrisse of 1857-58 to the second edition of The Capital of 1873 . It intends to offer the reader a contextualization about this problem, trying to demonstrate that the theoretical formulation of the fetishism of the commodity exposed in Capital is the result of intense earlier analyzes of Marx. Indeed, his intention is to bring the discussion to the fact that it is the thematic of reification exposed in the Grundrisse that engender the theoretical formulation of fetishism in Capital. Thus, within the context of this contextualization, we will make a problematization about the possible advances of this subject beyond the first chapter of Capital, whose analysis will be to demonstrate that the fetishism of the commodity brings together a set of burning questions for Marx, the which are exposed in works prior to 1873 when Marx published the second edition of Capital, which places the problematic of fetishism in a separate chapter, - and which show that they belong to the same theoretical bond related to the problem of reification and of fetishism as inseparable analytical categories.

KEY WORDS: Fetishism. Reification. Grundrisse. The capital.

\footnotetext{
* Graduado em Filosofia pela Universidade Federal Fluminense (UFF); Especialista em Filosofia pela Universidade Cândido Mendes (UCAM) e Mestre em Serviço Social pela Universidade Federal de Juiz de Fora (UFJF). E-mail: victor.rotciv_@hotmail.com.
} 


\section{INTRODUÇÃO}

Não é uma tarefa simples a de delimitar rigorosamente o início propriamente dito da temática do fetichismo na obra de Marx. Há boas razões para dizer que desde a juventude, expressivamente nos artigos que compõem os "debates sobre a lei referente ao furto de lenha", ${ }^{1}$ passando pelos Manuscritos econômico-filosóficos de 1844, quando especificamente trata da questão do dinheiro ${ }^{2}$ e da alienação, ${ }^{3}$ a temática do fetichismo parece tergiversar as preocupações de Marx nesses anos.

Contudo, uma investigação sobre as possíveis conexões no interior desse histórico do período de juventude de Marx referente à temática supracitada não constituirá nossa prioridade. Este artigo tem a modéstia pretensão de tomar exclusivamente como parâmetro para detectar os indícios referentes ao início da temática do fetichismo tão somente a partir dos rascunhos de 1857-58, os Grundrisse, e a partir daí, tomar como ponto de encontro sua exposição acabada em $O$ capital. Isto é, pretende demarcar um ponto de partida e um ponto de chegada à contextualização apoiada nesse liame temporal.

Hoje se pode dizer que, certamente, a exposição e formulação mais acabada sobre o fetichismo da mercadoria se encontra exposta no capítulo primeiro do Livro primeiro d' $O$ capital. Mas isso se apenas levarmos em consideração o fato de que em sua primeira edição, o capítulo dedicado ao fetichismo se encontrava mais bem disperso no exame das formas do valor. É tão somente na segunda edição do primeiro tomo d'O capital, corrigida e reeditada em 1873, portanto, seis anos depois de sua primeira edição destinada à impressão (1867), quinze anos depois da redação dos Grundrisse (1857-1858) e quase trinta anos posterior aos Manuscritos de 1844, que a passagem sobre o fetichismo da mercadoria encontra-se com um título especial e em "separado" do resto do primeiro capítulo.

\footnotetext{
1"Para os selvagens de Cuba, o ouro era o fetiche dos espanhóis. Eles organizaram uma celebração para ele, cantaram em volta dele e em seguida o jogaram ao mar. Caso tivessem assistido à sessão dos deputados renanos, os selvagens de Cuba não teriam considerado a madeira como o fetiche dos renanos? Porém, alguma sessão posterior lhes teria ensinado que o fetichismo está associado à zoolatria, e os selvagens de Cuba teriam jogado as lebres ao mar para salvar as pessoas." (MARX, 2017, p. 127).

${ }^{2 "}$ Veja-se de forma tergiversada, certas adjetivações de Marx (2012, p. 160-161) sobre o dinheiro que tangenciam a temática do fetichismo: "[...] Como o dinheiro, enquanto conceito existente e atuante do valor, confunde e troca todas as coisas, ele é então a confusão e a troca universal de todas as coisas, portanto, o mundo invertido, a confusão e a troca de todas as qualidades naturais e humanas."

${ }^{3}$ Há razões para supor que há uma conexão progressiva entre a temática da alienação e do fetichismo. Entretanto, ressaltamos apenas esta possibilidade, que compõe a dificuldade declarada. Haja vista que a inversão propriamente operada pelo fetichismo da mercadoria n' $O$ capital, insinua esse desdobramento. "O trabalhador se torna tanto mais pobre quanto mais riqueza produz, quanto mais a sua produção aumenta em poder e extensão. $\mathrm{O}$ trabalhador se torna uma mercadoria tão mais barata quanto mais mercadorias cria. Com a valorização do mundo das coisas aumenta em proporção direta a desvalorização do mundo dos homens.” (MARX, 2012, p. 80, grifo nosso).
} 
Artigo: Contexto e problematização do fetichismo na obra de Marx. Dos Grundrisse (1857-58) a $O$ capital (1873)

A formulação que recebe o fetichismo da mercadoria nessa segunda edição alemã resulta cabalmente em um dos escritos de Marx de maior maturação, haja vista que se trata de uma reelaboração feita pelo próprio Marx daquela edição destinada à impressão, e que sendo revisada toma definitivamente sua forma em um capítulo a parte. ${ }^{4}$ Segundo nosso ponto de vista, essa revisão criteriosa de 1873 coroa todo o primeiro capítulo d'O capital, precisamente pelas mudanças operadas nele tal como foi publicado em 1867 e de, essencialmente, dar cabo de reescrevê-lo com um último subcapítulo encabeçado com título próprio: "O caráter fetichista da mercadoria e seu segredo." ${ }^{5}$ Ao nosso ver, ao mesmo tempo em que expressa o quão legítima era a temática do fetichismo da mercadoria para Marx, suspende qualquer possibilidade de encará-lo como um mero fragmento isolado no interior do horizonte crítico de Marx em $O$ capital, e em outras de suas obras, especialmente os Grundrisse. ${ }^{6}$

Do modo que seja, a temática do fetichismo comparece desde as primeiras redações d'O capital, - notadamente os rascunhos de 1857-58 -, passa pela Contribuição à crítica da Economia Política (1859), até chegar à sua formulação acabada na segunda edição alemã do primeiro tomo d'O capital (1873).

A periodização que faremos, portanto, se apoia como princípio nos idos de 1857-1858 e vai até 1873, passo que ratifica a gênese e o desenvolvimento da temática do fetichismo na obra de Marx, até culminarem em sua exposição completa e coroada. Claro está que não

\footnotetext{
${ }^{4}$ Nesse período, Marx está elaborando os tomos II e III de sua magna obra. Para maiores informações sobre o esquema que sintetiza os fragmentos reunidos na nova versão de 1873 do primeiro capítulo, ver em Enrique Dussel (1990, p. 178-186). E também seu texto intitulado (1993). Excelentes indicações estão dadas nessas obras sobre a fundamental importância que teve essa segunda edição da obra d'O capital, tanto para a temática em torno do fetichismo, quanto para próprio conhecimento dessa revisão, em se tratando da anterior.

${ }^{5}$ Segundo o estudo que pudem fazer sobre tal questão, argumenta-se que o problema do fetichismo, na primeira edição de 1867 destinada à imprensa, se insere dentro do primeiro capítulo que levava por título "A mercadoria". Já na revisão e posterior publicação em 1873, da segunda edição, encontra-se em um subtítulo a parte. Pode-se afirmar isto em decorrência da sugestão feita por Kugelmann (1975, p. 57, tradução nossa), em correspondência de Marx, em julho de 1867, onde se lê: "Minha obra consta de aproximadamente 50 folhas. Veja o senhor que mal havia calculado seu volume. Há uns dias, enviei a Leipzig o suplemento, com o título "A forma do valor", anexo ao capítulo 1. O senhor conhece muito bem ao autor deste plano, ao que envio aqui meus agradecimentos por sua sugestão." Mas quase um mês antes Marx escreve a Engels que; "No que diz respeito ao desenvolvimento da forma valor, eu simultaneamente segui e não segui o seu conselho, atingindo, portanto, uma atitude dialética nestas questões, também. Isso pra dizer: 1) eu tenho escrito um appendix [apêndice] no qual eu demonstro, de novo, o mesmo assunto tão simplesmente e tão ao modo de um livro escolar quanto possível; e 2) eu dividi cada nova proposição em parágrafos etc., cada um com seu próprio cabeçalho, como você aconselhou" (MARX, 1867).

${ }^{6}$ Tentaremos demonstrar que a interpretação que vincula a temática do fetichismo apenas no primeiro capítulo d'O capital é bastante problemática. Tal como a que priorize tão somente essa condição, dispensando seu desenvolvimento já nos Grundrisse, e sequer mencionando a diferença entre a primeira edição (1867) e a segunda (1873) do primeiro tomo d'O capital, em se tratando dessa questão. Como exemplar desta interpretação está o dicionário dirigido por Tom Bottomore, o qual diz que: "A teoria do fetichismo da mercadoria nunca é retomada explicitamente e mais extensamente em $O$ capital, ou em qualquer outra obra de Marx" (BATTOMORE, 2012, p. 243).
} 
percorremos toda a imensa quantidade de cadernos, manuscritos e rascunhos desse período temporal $^{7}$ no intuito de fazermos uma longa exposição de suas particularidades, mas tão somente em demonstrarmos que a temática do fetichismo no interior desse longo itinerário intelectual de Marx tem começo, desenvolvimento e fim. Isso implica dizer, consequentemente, que para nós, a temática do fetichismo tem sua própria "linha de força" na obra marxiana, - em se tratando do período delimitado - se encontra nos rascunhos preparatórios d'O capital, os Grundrisse, passa pela Contribuição (1859), e chega a sua formulação final a qual é coroado com um capítulo à parte em sua teoria do valor no primeiro tomo da segunda edição alemã d'O capital (1873).

É do conhecimento da maior parte dos intérpretes, junto às leituras que pudemos fazer dos Grundrisse, que a temática do fetichismo não aparece cabalmente formulada. Este não possui um capítulo exclusivo, tal como não possui um destaque particular, senão como um aspecto implícito em suas análises do dinheiro e do trabalho abstrato, - tal como na questão do estranhamento -, inclusive no que diz respeito ao exame que submete de sua teoria do valor. Pode-se dizer, por isso, que a temática do fetichismo permanece tergiversada como um "conteúdo de fundo" no itinerário de Marx, especificamente quando trata da questão do dinheiro e das primeiras análises sobre a teoria do valor-trabalho, mas não dispõe de nenhuma exclusividade. Exemplar a este respeito são os manuscritos de $1861-1863^{8}$ em que o capítulo denominado "O rendimento e suas fontes" é emblemático, em se tratando da análise $\mathrm{d} O$ capital a juros, sem que seja dedicado ao fetichismo um capítulo exclusivo.

Os Grundrisse, como se sabe, representa o laboratório intelectual de Marx, tanto em seu sentido preparatório, quanto por seu conteúdo de registro - os oito cadernos que compõem os “Grundrisse der Kritik der Politischen Ökonomie Rohentwurf” representam o grande empenho de Marx no museu britânico ${ }^{9}$, período de profunda pobreza pessoal acompanhado de

\footnotetext{
${ }^{7}$ Quanto a este ponto, há que se ressaltar que o manuscrito de 1861-1863, posterior aos Grundrisse e segundo consta é sua própria continuação, e que leva o mesmo nome do livro publicado em 1859 (Contribuição à crítica da economia política), - porém sendo distintos deste -, não servirá de base para nosso estudo exclusivamente pelo fato de não reencontrar que versões nem em português nem em castelhano, respectivamente. Possivelmente há edições em alemão, às quais não pudemos ter acesso e nas quais muito provavelmente há boas indicações ao estudo do fetichismo.

${ }^{8}$ Utilizamos como marco referencial o capítulo mencionado traduzido e organizado por GIANOTTI (1991). Parte do qual está incluído nos respectivos manuscritos de 1861-1863, os quais Marx escreve já tendo concluído os esboços preparatórios para $O$ capital iniciados em 1857 e conhecidos sob o nome de Teorias sobre a maisvalia, a qual foi inserida em outra, sob o título de Para a crítica da economia política, correspondendo este título a uma introdução de um trabalho mais amplo, - leia-se, histórico -, que deveria conservar o mesmo nome do texto publicado em 1859, mas que diferia deste.

9 "De fato, uma vez instalado em Londres, Marx inicia um longo período de estudos, que registra em seus Extratos ou Cadernos de notas - pois sem recursos, tinha de copiar extratos para não comprar livros. Comparecia diariamente à biblioteca do Museu Britânico” (DUSSEL, 2012, p. 23). É imprescindível ressaltar o
} 
Artigo: Contexto e problematização do fetichismo na obra de Marx. Dos Grundrisse (1857-58) a $O$ capital (1873)

inúmeras dificuldades, que vai de julho de 1857 a dezembro de $1858^{10}$ e que podem trazer-nos a imagem de um período fronteiriço na vida de Marx. Nos Grundrisse temos a síntese de uma caminhada, é o resultado de intensas pesquisas anteriores, junto ao calor da revolução de 1848. ${ }^{11}$ Nesse período, Marx começa a salientar a temática do fetichismo, - repitimos, não com um capítulo exclusivo dedicado à análise da mercadoria -, pela via do aspecto "coisal" que assume o dinheiro frente às mercadorias.

O caráter social da atividade, assim como a forma social do produto e a participação do indivíduo na produção, aparece aqui diante dos indivíduos como algo estranho, como coisa; não como sua conduta recíproca, mas como sua subordinação a relações que existem independentemente deles e que nascem do entrechoque de indivíduos indiferentes entre si. A troca universal de atividades e produtos, que deveio condição vital para todo indivíduo singular, sua conexão recíproca, aparece para eles mesmos como algo estranho, autônomo, como uma coisa. (MARX, 2011a, p. 105).

Note o leitor como esta passagem dos Grundrisse sinaliza explicitamente para a temática de nosso estudo, tanto para o conteúdo propriamente relacionado ao fetichismo da mercadoria exposto em $O$ capital, quanto pela forma com que este começou a se desenhar no itinerário marxiano nos idos de 1857-58. A periodização que trazemos tem em vista a delimitação precisa acerca dessa dupla constatação: 1) de que o conteúdo da temática do fetichismo em $O$ capital parece ter nos Grundrisse sua matriz referencial; 2) ao mesmo tempo expressa seu processo de desenvolvimento analítico até $O$ capital. Pois quando Marx se dispõe a analisar os circuitos d $O$ capital, ${ }^{12}$ por exemplo, ele não faz mais do que desdobrar o mesmo aspecto "coisal" e autonomizado do dinheiro, estendendo-o posteriormente para o exame da maquinaria, autonomizada frente ao trabalhador. Há razões para dizer que esse aspecto "coisal", no centro em torno do qual se encrava a temática da reificação, é uma

quanto trabalhou Marx neste período, Dussel enumera cerca de 22 economistas nos quais Marx tomou diversas notas.

10 "Em julho, toma notas de uma obra de Bastiat e de Carey. Na última semana de agosto de 1857, inicia o Caderno M, que é pensado como "Introdução" aos Grundrisse. De outubro de 1857 a junho de 1858, escreve os Cadernos I ao VII dos Grundrisse; de junho a dezembro de 1858 toma ainda alguns apontamentos, elabora índices, escreve cartas e uma primeira redação (o Urtext) de Contribuição à crítica da economia política [...]" (DUSSEL, 2012, p. 24).

${ }^{11}$ Maiores informações sobre os Grundrisse e o contexto da atividade de Marx, ver em: (ROSDOLSKY, 2001) Também Enrique Dussel (2012).

12 “[...] Será considerado posteriormente que a forma mais extrema do estranhamento, forma em que, na relação $\mathrm{d} O$ capital com o trabalho assalariado, o trabalho, a atividade produtiva, aparece em relação com as suas próprias condições e com seu próprio produto, é um ponto de passagem necessário - e, por isso, encerra em si, ainda de forma invertida, de cabeça para baixo, a dissolução de todos os pressupostos limitados da produção, e, mais ainda, cria e produz os imprescindíveis pressupostos da produção e, em consequência, as condições materiais plenas para o desenvolvimento total, universal, das forças produtivas do indivíduo." (MARX, 2011, p. 687).

Sapere aude - Belo Horizonte, v. 9 - n. 18, p. 122-141, jul./Dez. 2018 - ISSN: 2177-6342 
constante nos Grundrisse. Tal como sinaliza ser este o percurso de Marx para a elaboração que terá o fetichismo da mercadoria.

Há excelentes razões para dizer que a temática propriamente do fetichismo da mercadoria contou, para sua exposição acabada em $O$ capital, com o exame feito por Marx nos Grundrisse, precisamente pela noção de coisificação ou reificação das relações sociais mediadas pelo dinheiro, ${ }^{13}$ e de sua separação e inclusão no processo. ${ }^{14}$ Isto é, o que algumas análises marxianas demonstram, nos Grundrisse, é que é pela reificação que Marx começa a engendrar uma concepção própria do caráter fetichista das mercadorias e de seu segredo, e não o contrário.

É importante notar que a riqueza enquanto tal, i.e., a riqueza burguesa, é sempre expressa na potência mais elevada no valor de troca, em que ela é posta como mediadora, como a mediação dos próprios extremos de valor de troca e valor de uso. Esse termo médio aparece sempre como a relação econômica consumada, porque ele contém as antíteses e finalmente aparece sempre como uma potência unilateral superior diante dos próprios extremos; porque o movimento, ou a relação, que originalmente aparece como mediador entre os extremos necessariamente prossegue de forma dialética até que ele aparece como mediação consigo mesmo, como o sujeito do qual os extremos são apenas momentos, extremos dos quais ele supera o pressuposto autônomo para se pôr, por meio da própria superação destes, como a única coisa autônoma. (MARX, 2011, p. 263).

É nesse processo de desenvolvimento teórico dos Grundrisse que, segundo cremos, a temática do fetichismo, a partir da reificação, vai tomando certa formatação. Ao mesmo tempo, ela sinaliza ter sido este o percurso que levou Marx à sua exposição.

Se o critério for o da inversão operada pelo fetichismo da mercadoria, - e que já comparece nos Grundrisse implicitamente através do mecanismo da reificação das relações sociais postas pelo dinheiro, - temos razões para afirmar que pelo fato de os objetos aparecerem aos indivíduos como "coisa", que existe e subsiste como se fosse deles independente, tem-se necessariamente aí implicado o problema do fetichismo.

[...] a dependência recíproca e multilateral dos indivíduos mutuamente indiferentes forma sua conexão social. Essa conexão social é expressa no valor de troca [...]; o indivíduo tem de produzir um produto universal - o valor de troca, ou este último por si isolado, individualizado, dinheiro. [...] o poder que cada indivíduo exerce sobre a atividade dos outros ou sobre as riquezas sociais existe nele como o

\footnotetext{
13 " [...] No valor de troca, a conexão social entre as pessoas é transformada em um comportamento social das coisas; o poder [Vermögen] pessoal, em poder coisificado." (MARX, 2011, p. 105).

14 "A determinação do produto em valor de troca implica necessariamente, que o valor de troca adquira uma existência separada e desprendida do produto. $\mathrm{O}$ valor de troca desprendido das próprias mercadorias e ele próprio existente junto delas como mercadoria é dinheiro." (MARX, 2011, p. 94).
} 
proprietário de valores de troca, de dinheiro. Seu poder social, assim como seu nexo com a sociedade, [o indivíduo] traz consigo no bolso. (MARX, 2011, p. 102-103).

Ou seja, sem os aportes coletados nos Grundrisse sobre a reificação, torna-se profundamente difícil compreender, ainda que em linhas gerais, o decurso de periodização da referida temática. A rigor, elas se conectam como elos indissociáveis ${ }^{15}$ de uma mesma questão vinculada à dimensão desse nexo "coisal" que o dinheiro estabelece entre os indivíduos como expressão da perda de controle deles das condições de existência sociais de suas relações entre si. Isso por sua vez inclui a temática do fetichismo de forma explícita. Pois é precisamente esse caráter "coisal" do dinheiro, existindo autonomamente e fora do controle consciente dos indivíduos, que Marx começa a descobrir, que o problema do fetichismo é um problema central no exame da teoria do valor e, principalmente, de sua crítica à economia política.

[...] o materialismo tosco dos economistas, de considerar como qualidades naturais das coisas as relações sociais de produção dos seres humanos e as determinações que as coisas recebem, enquanto subsumidas a tais relações, é um idealismo igualmente tosco, um fetichismo que atribui às coisas relações sociais como determinações que lhe são imanentes e, assim, as mistifica. (MARX, 2011, p. 575).

Note-se que o termo fetichismo refere-se aqui ao "materialismo tosco dos economistas" - materialismo este que é também uma forma de idealismo - ao qual são atribuídas relações sociais às coisas, mistificando, portanto, sua compreensão correta.

Pode-se dizer que, por essa citação, Marx esteja enunciando uma crítica acerca do caráter mistificador do materialismo dos economistas que acaba por naturalizar o objeto analisado, precisamente por eternizar as relações sociais de produção propriamente burguesas; as relações historicamente determinadas da produção burguesa são tomadas pelos economistas como relações naturais supra-históricas, cujo fetichismo constitui seu núcleo constitutivo. Com efeito, o termo parece comparecer aqui enquanto acusação enfática acerca das concepções de mundo que ostentam os economistas, tomando como natural algo de historicamente demarcado, algo que indica ser o fetichismo um fenômeno da consciência. Mas note-se, o problema não se esgota aí. Os Grundrisse oferecem uma gama imensa de travejamentos fundamentais para o decurso que Marx irá promover para concluir a temática do fetichismo. Veja-se, por exemplo, o seguinte:

\footnotetext{
15 “[...] Os próprios economistas dizem, nesse caso, que os homens depositam na coisa (no dinheiro) a confiança que não depositam em si mesmos como pessoas. Mas por que depositam a confiança na coisa? Evidentemente, só como relação coisificada das pessoas entre si, como valor de troca coisificado, e o valor de troca nada mais é do que uma relação da atividade produtiva das pessoas entre si.” (MARX, 2011, p. 162).
} 
[...] na máquina e mais ainda na maquinaria como um sistema automático, o meio de trabalho é transformado quanto ao seu valor de uso, i.e., quanto à sua existência material, em uma existência adequada a $O$ capital fixo e a $O$ capital como um todo [...] a própria máquina, que para o trabalhador possui destreza e força, é o virtuose que possui sua própria alma nas leis mecânicas que nela atuam e que para seu contínuo automovimento consome carvão, óleo etc. matérias instrumentais, da mesma maneira que o trabalhador consome alimentos. (MARX, 2011, p. 930, grifo nosso).

Há razões para supor que nesta passagem encontra-se situado o problema do fetichismo a nível objetivo, especificamente contra o fetichismo tecnológico, estabelecido em jargões das mais variadas estirpes, de uma espécie de "endeusamento" da técnica em detrimento dos homens, e da perda referencial do controle destes sobre aquela quando se completa a inversão operada pelo fetichismo: a personificação das coisas e reificação das pessoas. Mas não de modo irracionalista, como se algo inerente às máquinas e à técnica "corrompesse" os homens, mas na relação de propriedade em que tais máquinas operam e com a finalidade exclusiva da geração de mais-valor, aspecto tornado possível no capitalismo com o aval da ciência.

A ciência, que força os membros inanimados da maquinaria a agirem adequadamente como autômatos por sua construção, não existe na consciência do trabalhador, mas atua sobre ele por meio da máquina como poder estranho, como poder da própria máquina. [...] O processo de produção deixou de ser processo de trabalho no sentido de processo dominado pelo trabalho como unidade que o governa. Ao contrário, o trabalho aparece unicamente como órgão consciente, disperso em muitos pontos do sistema mecânico em forma de trabalhadores vivos individuais, subsumido ao processo total da própria maquinaria, ele próprio só um membro do sistema, cuja unidade não existe nos trabalhadores vivos, mas na maquinaria viva (ativa), que, diante da atividade isolada, insignificante do trabalhador, aparece como organismo poderoso. $\mathrm{Na}$ maquinaria, o trabalho objetivado se contrapõe ao trabalho vivo no próprio processo do trabalho como o poder que o governa, poder que, de acordo com sua forma, $O$ capital é como apropriação do trabalho vivo. A assimilação do processo do trabalho como simples momento do processo de valorização d $O$ capital também é posta quanto ao aspecto material pela transformação do meio de trabalho em maquinaria e do trabalho vivo em mero acessório vivo dessa maquinaria, como meio de sua ação. (MARX, 2011, p. 930).

É preciso dizer, ademais, que não foi por acaso que elencamos o problema da tecnologia em Marx como contraponto às ilações promovidas pelo irracionalismo hodierno, no que tange a qualquer acusação de caráter "crítico" desta sobre o primeiro, em se tratando 
do problema supracitado. ${ }^{16}$ Pois a precisão da crítica marxiana nos Grundrisse à tecnologia comparece de forma extremamente atual no que concerne ao poder social que adquire sobre os seres humanos, em que a própria ciência burguesa ratifica suas funções na inversão social que opera e legaliza. Veja o leitor atentamente uma passagem dos Grundrisse especificamente sobre esta questão.

Na maquinaria, o trabalho objetivado se contrapõe materialmente ao trabalho vivo como o poder dominante e como subsunção ativa deste a si [..] A acumulação do saber e da habilidade, das forças produtivas gerais do cérebro social, é desse modo absorvida no capital em oposição ao trabalho, e aparece consequentemente como qualidade do capital [...] Ademais, na medida em que a maquinaria se desenvolve com a acumulação da ciência social, da força produtiva como um todo, o trabalho social geral não é representado no trabalhador, mas no captial. $O$ saber aparece na maquinaria como algo estranho, externo ao trabalhador; e o trabalho vivo é subsumido ao trabalho objetivado que atua autonomamente. (MARX, 2011, 932933, grifos nossos).

\section{REIFICAÇÃO E FETICHISMO}

Como se pode ver, sutil e minuciosa, a temática da reificação nos Grundrisse compõe o itinerário de Marx para a elaboração da categoria do fetichismo em $O$ capital. O que é também, por sua vez, patente logo no ano seguinte aos Grundrisse, quando Marx publica o livro Contribuição à crítica da economia política (1859), e que já demonstra, de forma cabal, conter in nuce a temática do fetichismo da mercadoria.

Enfim, o que caracteriza o trabalho que cria valor de troca é que as relações sociais das pessoas aparecem, por assim dizer, invertidas, como a relação social das coisas. [...] Se é correto dizer, pois, que o valor de troca é uma relação entre as pessoas, convém ajuntar; uma relação oculta sob uma envoltura material. (MARX, 2008, p. 60, grifos nossos).

\footnotetext{
16 “[...] Uma boa aparência é dádiva da sorte, mas saber ler e escrever é um dom da natureza." (MARX, 2013, p. 158). É comum ouvir dos mais variados modos que Marx era um apologista da tecnologia. Elencamos aqui uma "síntese" possível para este tipo de querela: "[...] Além do mais, o mainstream progressista dos teóricos sociais do século XIX avaliou a evolução técnica como algo positivo e diferenciou-se somente em grau o entusiasmo pelo "progresso industrial". Karl Marx e Friedrich Engels, opositores radicais do capitalismo industrial, compartilharam, todavia, com seus contemporâneos a visão positiva do desenvolvimento técnico, interpretada como base do aumento da produtividade do trabalho. A teoria da mais-valia relativa, desdobrada nO capital de Marx seria impensável sem uma avaliação do avanço técnico e do seu papel no processo de aumento da produtividade do trabalho. Marx documenta a sua plena consciência da função fundamental da formação da organização fabril, da integração sistemática de fontes fósseis de energia e da criação da maquinaria industrial para o desenvolvimento da sociedade capitalista. Todavia, prende-se o autor à ideia de que o progresso social estaria necessariamente ligado ao avanço técnico, avaliação que impossibilitava consequentemente o desenvolvimento de uma crítica também das forças produtivas" (BRÜSEKE, 1998).
} 
É bastante vantajoso assumir a interpretação segundo a qual há uma transição da temática do dinheiro nos Grundrisse, para a temática do fetichismo em $O$ capital, em que a reificação parece tangenciar a ambos, no que se refere às argutas análises que Marx submete da mercadoria e do trabalho abstrato na Contribuição, em $1859^{17}$. Pois do contrário, corre-se o risco de supor uma espécie de "salto" unilateral entre os mesmos problemas, e paga-se o preço de apreender o fetichismo da mercadoria enquanto um mero "termo" com o qual arbitrariamente se "encaixa" na teoria do valor de Marx, sem que possua um histórico progressivo que a sustente.

Isto é, o fetichismo da mercadoria propriamente dito, exposto na segunda edição d'O capital com um título próprio, é a culminação de uma série de análises anteriores, cujo coroamento no primeiro capítulo só foi possível em relação às formulações de Marx nos Grundrisse sobre a reificação, combinadas com algumas passagens do texto de 1859, cujo tratamento do trabalho abstrato e da mercadoria revestia seu conteúdo de fundo. Não é casual, portanto, que o primeiro capítulo do texto de 1859 se intitule "A mercadoria", - tal como na primeira edição d'O capital em 1867 - e que, diferentemente dos Grundrisse, não começa pela análise do dinheiro. Isto é absolutamente central para o desdobramento do "caráter fetichista das mercadorias e seu segredo" na segunda edição de 1873, em que expressa, segundo nosso parecer, a complexidade analítica que revestiu sua exposição correlata, como se pode constatar em alguns dos desdobramentos no texto de 1859 sobre a referida questão.

\begin{abstract}
A natureza não produz dinheiro, nem tampouco os banqueiros, nem um curso de câmbio. Mas, já que a produção burguesa tem que cristalizar a riqueza como fetiche, sob a forma de um objeto isolado, o ouro e a prata é sua encarnação adequada. O ouro e a prata não são naturalmente dinheiro, mas o dinheiro é naturalmente ouro e prata. (MARX, 2008a, p. 196, grifos nossos).
\end{abstract}

Ao longo de toda sequência analítica de Marx, na qual expusemos em linhas gerais seus desdobramentos principais no que se refere à temática do fetichismo - partindo dos

17 Pode-se dizer que a temática do trabalho abstrato no texto de 1859 caracteriza, desde já, a forma indireta da relação social dos produtos do trabalho. "[...] Suposto o valor de uso da mercadoria, supõe-se também a utilidade particular, o fim determinado do trabalho que absorveu; mas aqui se detém, do ponto de vista da mercadoria, qualquer consideração do trabalho como trabalho útil. O que nos interessa no pão, como valor de uso, são as propriedades alimentícias, e de nenhum modo os trabalhos do lavrador, do moleiro, do padeiro etc. Se graças a algum invento desaparecessem os 19/20 desses trabalhos, o pão prestaria o mesmo serviço que antes. Se caísse do céu já cozido, não perderia por isso nenhum átomo de seu valor de uso. Enquanto o trabalho que cria o valor de troca se realiza na igualdade das mercadorias como equivalentes gerais, o trabalho, que é a atividade produtora tornada própria para um fim, realiza-se na infinita variedade de seus valores de uso. Enquanto o trabalho, criador do valor de troca, é trabalho geral-abstrato e igual, o trabalho criador do valor de uso é trabalho concreto e especial que, no que concerne à forma e à matéria, se decompõe em modos de trabalho infinitamente vários" (MARX, 2008, p. 62). 
Artigo: Contexto e problematização do fetichismo na obra de Marx. Dos Grundrisse (1857-58) a $O$ capital (1873)

Grundrisse, - tem-se como fundamental os cadernos que levam por título o mesmo do texto de 1859, - Contribuição à crítica da economia política - o qual foi previsto para compor a terceira parte d'O capital (o Tomo III), e tendo sido redigido em 1863, no qual, especificamente no capítulo intitulado "O Rendimento e suas Fontes. A economia Vulgar,"18 traz consigo a temática do fetichismo como central. Nesse capítulo em específico se expõe o fetichismo no exame dO capital a juros, como se vê:

\begin{abstract}
A forma e as fontes do rendimento (revenue) exprimem as relações da produçã $O$ capitalista sob a forma mais fetichista. Sua existência, como surge na superfície, isola-se de suas conexões ocultas e dos elos intermediários mediadores. [...] A forma distorcida em que se expressa a inversão efetiva se encontra naturalmente reproduzida na representação dos agentes deste modo de produção. Este é um modo de ficção sem fantasia, uma religião do vulgar. Os economistas vulgares traduzem, [...] de fato, as representações, os motivos, etc., dos portadores envolvidos na produçã $O$ capitalista, nos quais ela se reflete apenas em sua aparência superficial. (MARX, 1991, p. 211, grifos nossos).
\end{abstract}

Note-se a centralidade que a temática do fetichismo adquire nesse período maduro de Marx (1863) e como, de algum modo, reveste seus itinerários críticos, desde os Grundrisse, passando pelo texto de 1859 , até culminar na exposição completa e acabada d'O capital em sua segunda edição de 1873.

Apesar dessa breve periodização que trouxemos da temática do fetichismo na obra de Marx no período de 1857 a 1873, podemos arriscar uma interpretação em que afirme que ela "nasça" enquanto uma síntese analítica de longo percurso. Contudo, tais análises estão sempre vincadas na própria realidade - caso em que se afirme que o exame de Marx acerca do caráter “coisal" do dinheiro é, talvez, uma prévia para o exame do caráter fetichista das mercadorias e seu segredo - sendo, portanto, na própria realidade mercantil que os nexos sociais dos homens aparecem mediados pelo equivalente universal entanto núcleo de mediação deles. No que implica dizer que nos Grundrisse, pelo dinheiro e seu caráter "coisal”, encontramos Marx partindo da própria realidade social a qual, posteriormente, é pensada contendo uma objetividade fetichista invertida, inerente à forma social em que os produtos são necessariamente mediados pelo dinheiro, enquanto centro irradiador da personificação das

\footnotetext{
${ }^{18}$ Em carta de Marx a Kugelmann, datada de 11 de julho de 1868 encontramos a justificativa: "As garotas seguem melhor, ainda que, todavia, estejam fracas. Agradeço-lhe muito seus envios. [...] Tudo o que haverá conseguido será que, se sair uma segunda edição lhe darei a Bastiat, [...] sobre a magnitude do valor, seu merecido. Se isto não ocorreu ainda é porque o volume III deve conter um capítulo especial e detalhado sobre os senhores da "economia vulgar." [...] Em realidade, se jactam de seu apego à aparência, ao que consideram como a verdade última. Então, para que outra ciência?" Carta de Marx a Kugelmann (1975, p. 105, tradução nossa).
}

Sapere aude - Belo Horizonte, v. 9 - n. 18, p. 122-141, jul./Dez. 2018 - ISSN: 2177-6342 
coisas e coisificação das pessoas. O desdobramento analítico de Marx nos Grundrisse acerca do caráter "coisal" do dinheiro é, sem dúvida, um aporte essencial para seu decurso expositivo n'O capital. Como tal, é precisamente nas análises de 1859 sobre o trabalho abstrato e sobre a mercadoria que o fetichismo se cristaliza enquanto categoria objetiva da realidade social capitalista.

Isto é, enquanto uma síntese analítica de longo percurso, o fetichismo da mercadoria é a junção de uma série de análises feitas por Marx antes mesmo de expô-la em um capítulo a parte, na segunda edição d'O capital mas, ao mesmo tempo, reúne por sobre si mesma um feixe determinativo que lhe é próprio, diferindo e, talvez, prosseguindo, enquanto composição das análises do dinheiro, da mercadoria e do trabalho abstrato. Assim, o fetichismo da mercadoria revela-se enquanto categoria objetiva da realidade e síntese de múltiplas análises anteriores.

Característica, que segundo cremos, se complementa aos desarmes críticos que Marx oferece à economia vulgar nos idos de 1863, em que através da análise d $O$ capital a juros, pensada para o Livro III - a temática do fetichismo ganha não apenas compostura e posição própria, como também assevera sua legitimidade, em se tratando da inversão fetichista típica da economia vulgar e seus consortes. De tal maneira que Marx começa questionando a realidade social capitalista e a partir daí começa a formular uma compressão sui generis do fetichismo que lhe é própria, como também pretende torná-la uma categoria explicativa, - ao modo mais didático possível, como escreve a Engels - da própria realidade social coisificada do capitalismo, no Livro I. Desse modo, o fetichismo é ao mesmo tempo uma categoria objetiva da realidade social capitalista, como também envolve o discurso teórico do "materialismo tosco dos economistas" que impregna os imaginários anti-historicistas de suas ideias e concepções de mundo, tal como de suas personagens representativas - banqueiros, empresários, acionistas e proprietários fundiários, etc. Com efeito, são os próprios nexos sociais invertidos, coisificados, autonomizados que operam às costas dos sujeitos sociais $e$ as representações fantásticas e fantasmagóricas que no terreno ideológico se aderem enquanto justificativas em toda sorte de teoremas tão ou mais fetichistas, nas fórmulas "científicas" e de senso comum, cumprindo, por sua vez, uma função social específica no capitalismo. Em suma, diante deste nosso aporte, o fetichismo da mercadoria - iniciado, portanto, à luz dos Grundrisse, em que representa sua gênese - é desenvolvido como uma categoria central para Marx, em cujo processo de fundo se associa a seu empreendimento na própria "configuração" 
de alguns dos capítulos de seu livro III, por exemplo, ${ }^{19}$ e no exame submetido a $O$ capital a juros, tem-se uma resolução teórica dos mesmos aportes iniciados em 1857.

[...] Na forma do capital portador de juros, portanto, esse fetiche automático está elaborado em sua pureza, valor que valoriza a si mesmo, dinheiro que gera dinheiro, e ele não traz nenhuma marca de seu nascimento. A relação social está consumada como relação de uma coisa, do dinheiro. consigo mesmo. (MARX, 1985. Livro III. Tomo I, p. 294, grifo nosso).

Note-se o desdobramento analítico do fetichismo no exame do capital a juros e compare-se, apenas referindo-se aos termos empregados nos idos de 1863, à máxima expressão mística do modo de produção capitalista, para ter-se como suposto primário que a categoria fetichismo é um crescente na obra de Marx, e como tal, progrediu.

[...] Aqui a figura fetichista do capital e a concepção do fetiche-capital está acabada. Em D - D' temos a forma irracional dO capital: a inversão e reificação das relações de produção em sua potência mais elevada: a figura portadora de juros, a figura simples d $O$ capital, na qual este é pressuposto de seu próprio processo de reprodução; a capacidade do dinheiro, respectivamente da mercadoria, de valorizar seu próprio valor, independentemente da reprodução - a mistificação do capital em sua forma mais crua. (MARX, 1985a, grifo nosso).

O que os manuscritos de 1863 dispostos no Livro III d'O capital revelam é precisamente a forma em que $O$ capital assume em sua máxima expressão fetichista por suprimir as mediações sociais do processo.

O dinheiro cintila através de si mesmo, sem que os traços e rastros da exploração da força de trabalho apareçam como condições de sua luminosidade cintilante. Ao desaparecerem as mediações sociais do processo e o dinheiro assumir a figuração de "coisa" que pare filhotes por si próprio, ${ }^{20}$ completa-se o fetichismo, ou o "mais perfeito dos fetiches", "a forma pura do fetiche", o "fetiche automático", a relação de uma coisa (dinheiro) consigo mesma.

\footnotetext{
${ }^{19}$ No Livro III, leia-se o "CAP. XXI - O capital Portador de Juros." e "O CAP. XXIV - Alienação da RelaçãoCapital na Forma do capital Portador de Juros".

20 " [...] Ora, se tomarmos as formas particulares de manifestação que o valor que se autovaloriza assume sucessivamente no decorrer de sua vida, chegaremos a estas duas proposições: capital é dinheiro, capital é mercadoria. Na verdade, porém, o valor se torna, aqui, o sujeito de um processo em que ele, por debaixo de sua constante variação de forma, aparecendo ora como dinheiro, ora como mercadoria, altera sua própria grandeza e, como mais-valor, repele a si mesmo como valor originário, valoriza a si mesmo. Pois o movimento em que ele adiciona mais-valor é seu próprio movimento; sua valorização é, portanto, autovalorização. Por ser valor, ele recebeu a qualidade oculta de adicionar valor. Ele pare filhotes, ou pelo menos põe ovos de ouro." (MARX. 2013. Livro I, p. 230, grifo nosso).
} 
Para a Economia vulgar, que pretende apresentar o capital como fonte autônoma do valor, da criação de valor, essa forma é naturalmente um petisco, uma forma em que a fonte do lucro já não é reconhecível e em que o resultado do processo capitalista de produção adquire existência autônoma, separada do próprio processo. (MARX, 1985).

A fórmula do capital - D-D' - reduzida em seus próprios extremos e pressupostos torna a vida social uma mera adjacência de sua exuberância automática. Nesse estágio $\mathrm{d} O$ capital dinheiro o fetiche do capital alcança o poder de transmutar-se a partir de si próprio, fazendo desaparecer as mediações sociais e reduzindo-as a mero suporte de sua autovalorização.

Como capital portador de juros, e precisamente em sua forma diretamente como capital monetário portador de juros, as outras formas do capital portador de juros, que não nos interessam aqui, são por sua vez derivados dessa forma e a pressupõem, o capital recebe sua forma pura de fetiche, D - D' como sujeito, como coisa vendável (MARX, 1985b, grifo nosso)

Ao tornar oculta toda a multiplicidade de mediações sociais e reduzi-las a um único ciclo de dinheiro que gera mais dinheiro, a fórmula do capital a juros expressa, ademais, a dificuldade de tornar reconhecível a geração de mais-valor, ${ }^{21}$ convertendo a gradiente dos trabalhos que a produzem em mero suporte de uma relação "coisal."

No capital portador de juros, o movimento do caiptal é contraído; o processo intermediário é omitido e assim um capital $=1000$ é fixado como uma coisa que, em si, é = 1000 e, em determinado período, se transforma em 1 100, como o vinho na adega após certo tempo também melhora seu valor de uso. O capital é agora coisa, mas como coisa capital. O dinheiro tem agora amor no corpo. ${ }^{22}$ (MARX, 1985b, p. 295).

Note-se o prolongamento da temática "coisal" do dinheiro nesta passagem do Livro III d'O capital, que na verdade foi escrito em 1863. Note-se como se articulam no interior de uma mesma questão de fundo, note o leitor, portanto, que no capital a juros aparentemente desaparece a relação entre capital e trabalho, e ela condensa sob a forma fetichista de sua autonomização o capital como único e verdadeiro sujeito; subsume toda a sociabilidade como

\footnotetext{
21 “[...] E esse enraizamento do juro do capital monetário como numa coisa (como aparece aqui a produção da mais-valia pelo capital) [...] (MARX, 1985. Livro III. Tomo I, p. 295)

${ }^{22}$ Essa reiteração de Marx a uma citação de Goethe no Livro III faz parte de uma mesma menção no Livro I, em que diz: "[...] Ao transformar o dinheiro em mercadorias, que servem de matérias para a criação de novos produtos ou como fatores do processo de trabalho, ao incorporar força viva de trabalho à sua objetividade morta, o capitalista transforma o valor - o trabalho passado, objetivado, morto - em capital, em valor que se autovaloriza, um monstro vivo que se põe a "trabalhar" como se seu corpo estivesse possuído de amor." (MARX, 2013. Livro I, p. 271)
} 
Artigo: Contexto e problematização do fetichismo na obra de Marx. Dos Grundrisse (1857-58) a $O$ capital (1873)

seu objeto. $^{23}$ Com efeito, essa simples citação, acompanhada de nossas digressões demonstram, com alguma validade, que a personificação das coisas e a reificação das pessoas, além de serem aspectos e características do conteúdo e significado que assume o fetichismo da mercadoria em $O$ capital, no Livro I, fazem parte de uma longa e cruciante análise de Marx no decurso de muitos anos de investigação.

Além do mais, elas ratificam como a questão do fetichismo exposta no Livro I não é uma questão isolada, pois dá cabo de uma questão de fundo essencial para a crítica marxiana da economia política. É através da autonomização do capital na fórmula D-D' que a “coisa capital" ganha vida e aparece transformada em sujeito, sem mediação com o trabalho social. Note-se a inversão: ao desaparecer os nexos sociais do processo o capital assume a essência do processo e converte em seu automovimento a própria dinâmica das relações que o engendrou em mero fenômeno de sua fantasmagoria declarada. A própria sociabilidade tornase um suporte de sua autonomização profana, em cujo cerne encontram-se os bancos em relações com certos capitalistas industriais que depositam dinheiro nestes, os quais emprestam o dinheiro a outros capitalistas para que as orgias do ciclo de exploração da força de trabalho resulte em produtos, vendidos e convertidos em mais-valor e sejam devolvidos aos bancos em troca de juros.

E toda essa aparência invertida se retroalimenta numa "fórmula carente de sentido", numa "religião da vida cotidiana" 24 , na qual a superfície alienada traduz como sua própria subjetivação automática a forma mais fetichista do capital.

Reúnam-se tais citações dispostas nos manuscritos de 1863 com algumas das passagens elencadas por nós dos Grundrisse, para que se tenha em claro que a questão da autonomização, coisificação e mistificação faz parte da temática do fetichismo enquanto "elos indiscerníveis", unidos entre si por força do próprio objeto analisado por Marx, desde o dinheiro, a mercadoria e o trabalho abstrato. Caso em que na forma do capital a juros o fetiche do capital por tornar-se autossuficiente e não apresentar, à primeira vista, nenhuma dependência ao trabalho vivo, necessariamente ela ao mesmo tempo expressa um "materialismo tosco" que é também uma forma de idealismo a esta forma correlata. Ao apagar e subsumir diante de seu próprio automovimento todas as impressões condicionantes para seu

\footnotetext{
23 “[...] A figura acabada das relações econômicas, tal como se mostra na superfície, em sua existência real e, portanto, também nas concepções mediante as quais os portadores e os agentes dessas relações procuram se esclarecer sobre as mesmas, difere consideravelmente, sendo de fato o inverso, o oposto, de sua figura medular interna, essencial, mas oculta, e do conceito que lhe corresponde.” (MARX, 1985. Livro III. Tomo I, p. 160)

24 “[...] essa personificação das coisas e essa reificação das relações de produção, essa religião da vida cotidiana [...]" (MARX, 1985. Livro III. Tomo II, p. 280).
} 
existir - isto é, a extração de mais-valor, a exploração do trabalhador -, o capital-fetiche na forma dos juros autonomizados faz desaparecer o conteúdo do trabalho social.

Mas do ponto de vista da produção teórica de Marx, logo após este exame do capital a juros em 1861-1863 sucede seu "Capítulo VI inédito", escrito entre 1864-1865, o qual será passado em revista logo a seguir, também sob o prisma do fetichismo.

Este capítulo VI foi pensado primeiramente para o Livro I d'O capital. Foi destinado a compor o livro primeiro d'O capital, segundo indicado no próprio manuscrito, o qual acabou não sendo incluído neste. ${ }^{25}$ Contudo, neste manuscrito Marx volta a pensar $O$ capital e volta a submetê-lo sob o crivo do fetichismo. ${ }^{26}$

[...] chega-se a conclusão de que, como o processo de produção do capital é em geral processo de trabalho, assim, o processo de trabalho, em todas as formas sociais, é necessariamente processo de trabalho do capital. O capital é visto, desse modo, como coisa, que no processo de produção desempenha certo papel próprio de uma coisa, adequada a sua condição de coisa. (MARX, 1978, p. 13).

Ao que acrescenta, na mesma perspectiva, logo depois, o seguinte:

[...] é desse modo que, seja do ponto de vista do operário, seja do ponto de vista do capitalista - o meio de produção, enquanto modo de existência do capital, eminentemente como capital, se contrapõe ao trabalho, ao outro elemento no qual o capital adiantado se transforma, e, por conseguinte, aparece fora do processo de produção, potencialmente (dinamei), como modo de existência específico do capital. Como se verá, isso se desenvolve ulteriormente, em parte em decorrência da natureza geral do processo capitalista de valorização (do papel que nele desempenham os meios de produção, sugando trabalho vivo), em parte, como decorrência do desenvolvimento do modo de produção especificamente capitalista (no qual a maquinaria etc., se converte no verdadeiro dominador do trabalho vivo). Eis por que, na base do processo capitalista de produção, dá-se essa função indissolúvel dos valores de uso, na qual o capital existe sob a forma de meios de produção; e daí a determinação desses meios de produção, dessas coisas, como capital - que é uma relação de produção social determinada - exatamente do mesmo modo que, no seio desse modo de produção, os nele implicados consideram o

\footnotetext{
${ }^{25}$ Segundo consta, foi o próprio Engels quem separou esse manuscrito do livro I, o qual foi publicado muito posteriormente em 1933 em Moscou.

26 “'[...] o lucro, diferentemente da mais-valia, pode aumentar por força da utilização econômica das condições de trabalho coletivas, seja, por exemplo, porque se economiza nas edificações, no aquecimento, na iluminação etc, porque o valor da força motriz (prime motor) não cresce na mesma medida de sua potência; economias no preço da matéria-prima, nova utilização dos resíduos, diminuição dos custos de administração, dos grandes depósitos no caso de produção em massa etc; todas essas baixas de preços relativas do capital constante, junto ao aumento absoluto de seu valor, se fundamentam em que tais meios de produção - meios e materiais de trabalho empregam-se coletivamente, e essa utilização coletiva tem como premissa absoluta a cooperação conjunta de operários conglomerados, e, portanto, ela mesma não é mais do que a expressão objetiva do caráter social do trabalho e da força produtiva social que disso resulta; assim como em sua maior parte a forma particular dessas condições - por exemplo, maquinaria - não é aplicável fora do trabalho associado. Não obstante, frente ao operário que cai sob estas condições, elas se apresentam como dadas e independentes dele, como figuras do capital." (MARX, 1978 p. 85, grifo nosso).
} 
produto em si mesmo como mercadoria. E isso constitui uma base para o fetichismo dos economistas. (MARX, 1978a, p. 14, grifo nosso).

Note-se que Marx está retomando explicitamente a crítica àquele "materialismo tosco dos economistas" de tomarem as relações sociais como relação entre coisas, crítica que Marx submete em $O$ capital do início ao fim. Consequentemente, o que este manuscrito, o capítulo VI, nos revela, é precisamente o caráter progressivo da temática do fetichismo em relação ao decurso intelectual de Marx, ao mesmo tempo em que demonstra de forma central, a importância da temática do fetichismo para Marx. Estas duas condições se entrelaçam a uma terceira, qual seja: seu coroamento no Livro I.

A rigor, neste capítulo VI inédito, o que vemos é uma retomada mais ampla dos mesmos postulados analíticos coletados por nós, no que tange ao percurso da temática do fetichismo na obra de Marx. Note-se aquele problema ressaltado por nós sobre a autonomização da maquinaria no processo produtivo nos Grundrisse retorna aqui em novos lineamentos sobre a referida temática, por exemplo:

[...] ]em realidade, o consumo de meios de subsistência por parte dos operários pode ser compreendido (incluir-se) no processo de trabalho; se, por exemplo, inclui-se nas máquinas o consumo por elas efetuado de matérias instrumentais, do mesmo modo o operário apresenta-se apenas como instrumento, adquirido pelo capital, que para sua função no processo de trabalho necessita consumir, adicionar certa porção de meios de subsistência como suas matérias instrumentais. Isso ocorre em maior ou menor medida segundo a amplitude e brutalidade da exploração a que o operário é submetido. (MARX, 1978b, p. 15).

\section{CONCLUSÃO}

Evidencia-se que a temática do fetichismo comparece tergiversada na temática da reificação, na qual ambas parecem se complicar em virtude da inversão operada pela maquinaria no capitalismo.

[...] Em geral, o operário consome seus meios de subsistência quando se interrompe o processo imediato de produção, ao passo que a máquina consome os seus durante seu funcionamento (animal?). Se entretanto, considerarmos a classe operária em seu conjunto, veremos que uma parte desses meios de subisistência são consumidos pelos familiares que ainda não trabalham, ou que já não trabalham. Efetivamente, a diferença que existe na prática entre o operário e uma máquina pode reduzir-se, no que se refere às matérias instrumentais (quoad matiéres instrumentales) e a seu consumo, à que existe entre o animal e a máquina. (MARX, 1978b). 
Como se pode ver, as mesmas investigações marxianas dispostas já nos Grundrisse comparecem em sua maturidade.

\begin{abstract}
Os meios de produção utilizados pelo operário no processo real de trabalho são, certamente, propriedade do capitalista, e na condição de capital se defrontam - tal como vimos antes - com o trabalho, que é a própria manifestação vital do operário. Por outra parte, é ele quem os emprega em seu trabalho. No processo de trabalho efetivo, o operário consome os meios de trabalho como veículo de sua atividade, e o objeto de trabalho como a matéria na qual seu trabalho se apresenta. Por isso, precisamente, transforma os meios de produção na forma de produto adequado a um fim. Do ponto de vista do processo de valorização, entretanto, as coisas se apresentam diferentemtente. Não é o operário quem utiliza os meios de produção; são os meios de produção que utilizam o operário. Não é o trabalho vivo que se realiza no trabalho objetivo como em seu órgão objetivo; é o trabalho objetivo que se conserva e aumenta pela absorção do trabalho vivo, graças ao qual se converte em um valor que se valoriza, em capital, e como tal funciona. Os meios de produção aparecem unicamente como absorventes da maior quantidade possível de trabalho vivo. Este apresenta-se apenas como meio de valorização de valores existentes, e, por conseguinte, de sua capitalização." (MARX, 1978b, grifo nosso)
\end{abstract}

A temática do fetichismo é uma constante neste "capítulo VI", diria, com algumas ressalvas, que aparece muito mais do que até mesmo no primeiro capítulo d'O capital, vale ressaltar o quanto ele representa, em se tratando de nossa temática, a progressão de Marx a respeito da reificação e do fetichismo.

[...] E, prescindindo-se do que foi assinalado antes, justamente por isso os meios de produção aparecem de novo e se defrontam com o trabalho vivo na qualidade de modo de existência do capital, e, agora, como domínio do trabalho passado e morto sobre o trabalho vivo. Justamente como criador de valor o trabalho vivo se incorpora de maneira constante, no processo de valorização, ao trabalho objetivado. Como esforço, como dispêndio de força vital é a atividade pessoal do operário. Mas, enquanto criador de valor, implicado no processo de sua objetivação, o próprio trabalho do operário é, tão logo ingressa no processo de produção, um modo de existência do valor do capital, a este incorporado. Essa força conservadora do valor e criadora de novo valor é, em consequência, a força dO capital, e, muito mais, da pauperização do operário, o qual, criando um valor, cria-o ao mesmo tempo como um valor que the é alheio. (MARX, 1978b, grifos nossos).

São diversas as passagens que legitimam a temática do fetichismo, no decurso dos idos de 1864-1865, sendo que todas as que estão sendo elencadas aqui pretendem unicamente demonstrar que é legítima e tem sua razão de ser no marco da progressão analítica de Marx sobre a referida temática.

No tocante à produção capitalista, essa faculdade do trabalho objetivado de transformar-se em capital, isto é, de transformar os meios de produção em meios de direção e exploração do trabalho vivo, surge como algo inerente aos próprios meios de produção - a que, nesta base, está ligada potencialmente - como algo inseparável 
delas, e, por conseguinte, como qualidade que lhe corresponde na condição de coisas, enquanto valores de uso, enquanto meios de produção. Estes apresentam-se, então, em si mesmos, como capital, e o capital - uma vez que exprime uma relação determinada de produção, uma relação social determinada, em cujo seio os possuidores das condições de produção se defrontam com a capacidade viva de trabalho na condição de coisa -, do mesmo modo que o valor, aparecia como qualidade de uma coisa, e a determinação econômica da coisa como mercadoria, como qualidade de coisa; do mesmo modo pelo qual a forma social que o trabalho assumia no dinheiro, apresentava-se como qualidade de uma coisa. (MARX, 1978b, grifos nossos).

Logo à frente Marx sintetiza o levantamento feito por nós no que diz respeito à progressiva análise que promove da temática do fetichismo e da reificação:

[...] as funções exercidas pelO capitalista não são mais do que as do próprio capital do valor que se valoriza sugando o trabalho vivo - exercidas com consciência e vontade. O capitalista só funciona na condição de capital personificado: é o capital enquanto pessoa; do mesmo modo, o operário funciona unicamente como trabalho personificado, que lhe pertence como suplício, como esforço, mas que pertence ao capitalista como substância criadora e multiplicadora de riqueza. Esse trabalho apresenta-se de fato como um elemento incorporado ao capital no processo de produção, como seu fator vivo, variável. O domínio do capitalista sobre o operário é, por conseguinte, o da coisa sobre o homem, o do trabalho morto sobre o trabalho vivo, do produto sobre o produtor, já que, em realidade, as mercadorias, que se convertem em meios de dominação sobre os operários (mas apenas como meio de domínio do próprio capital), não são senão meros resultados do processo de produção, os seus produtos. (MARX, 1978b, grifos nossos).

O desdobramento da análise de Marx nesses manuscritos revela que a mistificação operada pelo capital possui um caráter objetivo, longe de serem aspectos e funções cumpridas apenas no interior das concepções ideais, incluem como pressupostos desta objetividade prioritária. São os próprios fatores objetivos, dinheiro e mercadoria, meios de produção e meios de subsistência que se defrontam aos trabalhadores como poderes autônomos personificados em seus possuidores. De tal maneira que o contexto da problemática do fetichismo mostrou ser um processo de síntese teórica em que incidem diversos temas. Disto tratou este artigo em particular, esperamos ter oferecido ao leitor uma contribuição acerca deste assunto.

\section{REFERÊNCIAS}

BOTTOMORE, T. Dicionário do pensamento Marxista. Rio de janeiro: Ed. Zahar, 2012. EDITORIAL DE CIENCIAS SOCIALES. Cartas a Kugelmann. Ed. Teoría Econômica. La Habana. 1975. 
DUSSEL, E. EI Último Marx (1863-1882) y la liberación latinoamericana. México: Siglo XXI. 1990.

DUSSEL, E. El fetichismo en las cuatro redacciones de El Capital (1857-1882). Madrid: Verbo Divino. 1993

DUSSEL, E. A produção teórica de Marx. Um comentário aos Grundrisse. Expressão Popular. 2012.

BRÜSEKE, Franz Josef. A crítica da técnica moderna. 1998. Disponível em: https://revistaesa.com/ojs/index.php/esa/article/view/123/119.

GIANOTTI, A.; REHFELD, W. Manuscritos Econômico-Filosóficos e Outros Textos Escolhidos. Ed. Nova Cultural. 1991.

MARX, K. Os despossuídos. Boitempo. 2017.

MARX, K. Manuscritos Econômico-Filosóficos. Boitempo. 2012.

MARX, K. Capítulo VI Inédito. Editora Ciências Humanas. 1978.

MARX, K. Grundrisse. Boitempo. 2011.

MARX, K. O capital. Crítica a Economia Política. Boitempo. 2013.

MARX, K. O capital. Crítica a Economia Política. Livro III. Tomo I. Nova Cultural. 1985.

MARX, K. O capital. Crítica a Economia Política. Livro III. Tomo II. Nova Cultural. 1985.

MARX, K. Contribuição a Crítica da Economia Política. Boitempo. 2008.

ROSDOLSKY, Roman. Gênese e Estrutura de $O$ capital de Karl Marx. Rio de Janeiro: EDUERJ: Contraponto, 2001. 